\title{
Biomaterials and Stem Cells in the Treatment of Articular Cartilage, Meniscal, Physeal, Bone, Ligamentous and Tendineous Defects
}

\author{
A. NEČAS ${ }^{1}$, L. PLÁNKA ${ }^{2}$, R. SRNEC ${ }^{1}$, P. RAUŠER ${ }^{1}$, L. URBANOVÁ ${ }^{1}, J^{\prime}$ LORENZOVÁ ${ }^{1}$, M. CRHA ${ }^{1}$, \\ J. JANČÁŘ ${ }^{3}$, P. GÁL ${ }^{2}$ \\ ${ }^{1}$ Department of Surgery and Orthopaedics, Small Animal Clinic, Faculty of Veterinary Medicine, \\ University of Veterinary and Pharmaceutical Sciences Brno, Czech Republic \\ ${ }^{2}$ Department of Pediatric Surgery, Orthopaedics and Traumatology, Faculty Hospital Brno, Czech Republic \\ ${ }^{3}$ Institute of Materials Chemistry, Brno University of Technology, Czech Republic
}

Received November 14, 2007

Accepted February 14, 2008

\begin{abstract}
Nečas A., L. Plánka, R. Srnec, P. Raušer, L. Urbanová, J. Lorenzová, M. Crha, J. Jančář, P. Gál: Biomaterials and Stem Cells in the Treatment of Articular Cartilage, Meniscal, Physeal, Bone, Ligamentous and Tendineous Defects. Acta Vet Brno 2008, 77: 277-284.

This review briefly summarizes existing results and main trends in experimental studies dealing with the possibilities of the use of biomaterials and mesenchymal stem cells in the treatment of diseases affecting tissues derived from the mesoderm, i.e. articular cartilage, meniscus, physis, bone, ligaments and tendons. The aim of these experimental studies is to find optimal forms of treatment of the diseases of individual parts of the musculoskeletal system using methods of tissue engineering with the use of stem cell transplantation.
\end{abstract}

Tissue engineering, mesenchymal stem cells, cartilage, physis, joint, meniscus

Optimally, the result of the injured tissue treatment should be complete regeneration of the original tissue, while maintaining the same functional properties of the tissue before injury. The aim of current experiments is to find such therapeutic methods and procedures that correspond as much as possible to this ideal therapy. The most perspective in this respect appears the use of not only newly developed biomaterials but especially the transplantation of stem cells (that have the potential to differentiate into a number of tissues), or possibly the transplantation of stem cells in combination with biomaterials.

The ability of mesenchymal stem cells to differentiate into tissues of mesoderm elicited great interest in experimental examining of the possibilities of their use in the treatment of injuries and defects of individual components of the musculoskeletal system (cartilages, bones, ligaments, muscles and tendons) (Ahn et al. 2004; Chen et al. 2003; Dressler et al. 2005; Gál et al. 2007; Hoemann et al. 2005; Lee and Hui 2006; Plánka et al. 2007; Shirley et al. 2005). In connection with the fulfilment of our research plan that focuses on the use of newly synthesized biomaterials in combination with stem cells in the treatment of diseases affecting tissues derived from mesoderm, we present a brief summary of existing uses and main trends of experimental applications of biomaterials of mesenchymal stem cells (MSC) in orthopaedics.

\section{Biomaterials}

The importance of newly developed biomaterials is partly in their independent use as biocompatible tissue substitutes, partly also in combination with stem cells to which they serve as a suitable scaffold in the process of transplantation (Jančář et al. 2007a). The scaffold properties play an important role in the implant incorporation into the target tissue. The 
scaffold serves stem cells in the first phase of healing as a live medium and a mechanical support, which requires specific mechanical and other properties that are different for each target tissue (bone, cartilage, ligaments) (Ferrari et al. 2007; Jančář et al. 2007b).

Among biomaterials for independent implantation into tissues may be mentioned implants intended for use in bone tissue, namely products developed on the basis of betatricalcium phosphate (ChronOs), or calcium-phosphate (Norian SRS) (Szpalski and Gunzburg 2002).

Biomaterials used as scaffolds for stem cells are a very diverse group, and individual products are developed using such methods that their properties are as similar as possible to the target tissue properties. Apart from using already traditional materials, such as hydroxyapatite (HA) for transplantation into bones, or collagen, chitosan or PGA-PLA (polyglycolic acid - polylactic acid) scaffold for transplantations into cartilaginous tissue, and a liquid solution of hylauronic acid for direct injection into the articular fluid, scaffolds with the required properties are being developed. An important task of current tissue engineering is the development of such scaffolds for the given target tissue that can withstand even mechanical load (Chen et al. 2000; 2002; Fang et al. 2005; Moroni et al. 2006; Risbud and Sittinger 2002). The search for suitable mechanical and structural properties is a highly topical issue (Ferrari et al. 2007; Jančář et al. 2007ab).

\section{Stem cells}

Stem cells are divided into two basic types: embryonic and mesenchymal. Embryonic stem cells are pluripotent; they are characteristic for their exclusively allogeneic use (despite their good immunological toleration in vivo), and mainly for a high risk of teratome formation (Smith 2006). Postnatally derived cells with a lower level of differentiation (multipotent) are labelled as adult. This group includes haematopoietic cells and mesenchymal stem cells (Smith 2006).

Mesenchymal stem cells are cells of mesodermal origin that have the ability to differentiate into osteoblasts, chondrocytes, tenocytes, fibroblasts, myofibroblasts or adipocytes (Lee and Hui 2006; Smith 2006). Mature stem cells are in small numbers present in most tissues. The most suitable source of their obtaining is the bone marrow, although other potential sources may be used as an alternative, such as fatty tissue, periosteum, or funicular blood (Hui et al. 2005). After mature stem cells are collected from the bone marrow, they are isolated into culture medium (e.g. Dulbecco's Modified Eagles Medium (DMEM), Gibco Laboratories, Life Technologies, Grand Island, NY), where the cells gradually multiply. After obtaining a certain number of cells in the colony, these may be used for therapeutic transplantation as auto- or allograft. In contrast to haematopoietic stem cells that cannot be easily multiplied in vitro, mesenchymal stem cells during their expansion in culture media maintain their ability to differentiate into mesenchymal tissues. Considering the fact that the source of these cells is most frequently the bone marrow, some authors label them as "stromal bone marrow cells" (Pluhar 2004). It is possible to label transplanted MSCs in various ways (Terrovitis et al. 2006) and consequently to demonstrate in various ways that the newly formed cells of the receptor have differentiated precisely from the implanted MSCs. Among common methods may be named immunofluorescent stain incorporation and subsequent demonstration of its presence in the histopathological section (Plate VI, Fig. 1), the use of Resovist and its demonstration by Pearls' reaction (reaction with Berlin blue), or in vivo imaging during examination by magnetic resonance (Gál et al. 2007; Plánka et al. 2007). According to available studies, possibilities of the use of mesenchymal stem cells in the therapy of damaged musculoskeletal system tissues is wide, whether it be in the damage of intraarticular structures (articular cartilage, meniscus), physeal cartilages, bones, or even ligaments and tendons. 


\section{Articular cartilage lesion healing}

Possibilities of the use of mesenchymal stem cells in the treatment of articular cartilage defects have been the subject of interest of a number of scientists and they are studied e.g. in rabbits (Grande et al. 2003; Melamed et al. 2004), horses (Fortier et al. 1998; Wilke et al. 2001), or sheep (Hoemann et al. 2005). The results of the primary studies in rabbits suggested that MSCs could improve the articular cartilage healing. Some in vivo studies in horses, however, were not so convincing and showed that there may be certain difficulties with autologous MSCs obtained from the bone marrow in cultivation and multiplication. The most frequent site of transplantation in experiments is the knee joint, in particular the articular surface of femur (Newberry et al. 1997), exceptionally the articular surface of tibia (Yanai et al. 2005).

Methods are continuously investigated, that allow influencing chondrogenesis induction, e.g. by exposing MSCs to the effect of TGF- $\beta 1$, TGF- $\beta 2$, or TGF- $\beta 3$, Sox 5, 6 and 9, or BMP-2 or BMP-7 (Anitua et al. 2004; Carter 2003). Research shows that the biggest problem is the right timing of the series of effects of individual factors in order to create conditions for differentiation that are identical with the conditions in vivo.

The methods of transplantation also vary in individual studies, proving the continuous search for an optimal method. For example, there are descriptions of the use of a mixture of separated stem cells with atelocollagen gel ( $0.5 \%$ acidsoluble type-I collagen, obtained from bovine skin - Yanai et al. 2005), the use of PGA scaffold core with MSCs (Grane et al. 2003), the injection of a solution with stem cells into the articular cartilage defect with a subsequent overlay with a periosteal flap taken from tibia, and reinforcement using a fibrinous glue (Farnworth 2000), and the implantation of absorbable polymer in the form of platelets into the defect (O'Driscoll 1998). At present, our department focuses on research of the treatment of articular cartilage defects by mesenchymal stem cells in miniature pigs (Plate VI, Fig. 2) in combination with scaffolds on the basis of nanofibres and a mixture of collagen with chitosan (Jančář et al. 2007ab).

\section{Meniscal lesion healing}

Possible regeneration of damaged meniscal tissue is indicated by pre-clinical studies on the application of allogeneic mesenchymal stem cells by intraarticular injection one week after meniscectomy, when regeneration of the destructed meniscal tissue is stimulated (Pluhar 2004). The newly-formed meniscal tissue protects the joint from degenerative changes (osteoarthritis) that commonly develop in connection with these lesions. In comparison to the control group, in joints treated with stem cell application less serious articular cartilage damage is described, as well as less marked osteophyte formations (Pluhar 2004). Injection of stem cells directly into the affected joint is relatively simple and allows avoiding demanding surgical procedures (e.g. meniscus transplantation). At the same time, the newly-formed meniscal tissue corresponds to hyaline cartilage with the low number of cells and a high content of type II collagen (Pluhar 2004). At out department, we are preparing a model study on miniature pigs, in which stem cells will be transplanted into the knee joint after creating a partial meniscal lesion.

\section{Physeal defect healing}

Injuries of the growth cartilage of long limb bones lead in 5\% of cases to a clinically significant bone bridge formation between epiphysis and metaphysis of the long bone (Gál et al. 2002; Janarv et al. 1998). At the same time, in approximately $25-30 \%$ of cases the lengthwise bone growth is reduced and angular bone deformity developed (Campbell et al. 1959; Ford and Key 1956). Besides, $10 \%$ of them are associated with a joint function disorder (Mann and Rajmaira 1990). Regeneration capacity of the physeal growth plates after their traumatisation is low. Surgical interventions for the purpose of correcting these conditions are usually demanding (distraction epiphyseolysis, chondrodiatasis, or temporary 
growth arrest). Prophylactic interventions preventing bone bridge formation focus on the filling of the occurred articular cartilage defect mainly with an allogeneic fatty graft, a graft from fascia or tendon, or by silicone substitutes (Campbell et al. 1959; Österman 1972). Some studies indicate a positive effect of autologous chondrocyte transplantation to the growth cartilage defect (Gál et al. 2002). The actual issues of current research include evaluation of the capacity of mesenchymal stem cells to heal physeal defects. In our previous studies we dealt with the subject of MSC transplantation to injured growth plates in rabbits, mainly with the aim to find a suitable scaffold, and also to verify the possibilities of use of MSCs and to evaluate some aspects of auto- and allogeneic mesenchymal stem cell transplantations, particularly in connection with the treatment of physis after a bone bridge excision (Gál et al. 2007; Hui et al. 2005; Plánka et al. 2007).

One of our previous studies showed that prophylactic transplantation of autogenous mesenchymal stem cells to an iatrogenically generated defect in the distal growth plate of femur in rabbits leads to the prevention of bone bridge formation and allows physeal defect healing by hyaline cartilage (Plánka et al. 2007). Femur growth in traumatised physis was maintained after autogenous MSC transplantation, and compared to the femur with a generated physeal defect without MSC transplantation (control group), no marked shortening or valgus deformity of the bone occurred (Ahn et al. 2004; Chen et al. 2003; Hui et al. 2005; Plánka et al. 2007).

Another one of our studies focused on the MSC transplantation to the physeal defect aimed at determining whether allogeneic mesenchymal stem cells may functionally heal a defect in the distal growth plate of femur in the rabbit without immunosuppressive therapy (Gál et al. 2007). The results of the study prove that allogeneic mesenchymal stem cells in the new composite carriers (hyaluronate/type I collagen/fibrin) healed iatrogenic defects in the distal physis of femur in rabbits without the use of immunosuppressive therapy.

The use of allogeneic mesenchymal stem cells may therefore be an alternative to autologous transplantation of MSCs in the treatment of physeal defects. In clinical practice, such transplantation could lead to the use of MSCs from an unrelated donor, i.e. an easy source of cells needed for the cartilaginous tissue healing (Batten et al. 2006; Gál et al. 2007; Plumas et al. 2005). Currently, we are working on the verification of the possibilities of injured physis treatment in miniature pigs.

\section{Damaged bone tissue regeneration}

In the case of comminuted or otherwise complicated fractures with the loss of bone tissue, the use of bone grafts is indicated in the course of surgical intervention. Extensive bone defects occur with the loss of a considerable part of the bone in consequence of a trauma (fracture), or with bone resection in the treatment of a tumoral disease. Such defects may be treated by nowadays already accessible methods, such as bone morphogenetic proteins (BMPs); yet, mesenchymal stem cells currently appear more suitable for this indication, mainly for their ability to transform into cells capable of independently generating new bone tissue that may fill up the particular bone defect (Pluhar 2004).

Mesenchymal stem cells may be directed during cultivation to transform into lines capable of producing bone mass, by being exposed to the effects of a number of substances, such as the transforming growth factor (TGF), insulin-like growth factor (IGF), vascular endothelial growth factor (VEGF), dexamethasone, or glycerol phosphate (Anitua et al. 2004; Anitua et al. 2005; Carter 2003; Marx 2004; Pluhar 2004).

In some studies, MSCs were mixed with a biopolymer on the basis of hydroxyapatite (in particular, hydroxyapatite is described to have a markedly longer resorption time than calcium phosphate - ChronOs) (Szpalski and Gunzburg 2002). Further use of synthetic biomaterials is the subject of currently conducted investigations, as is the mixing of MSCs 
with autologous or allogeneic bone mass (DBM - demineralised bone matrix) (Goho 2004; Szpalski and Gunzburg 2002).

The implantation of the composite of MSCs and biomaterial is carried out according to the chosen carrier and localisation, e.g. by injecting (Norman SRS, ChronOs inject), by incorporating a little block of bioceramics (HA, ChronOs) (Arinzeh et al. 2003), by filling the cavity (ChronOs granules) or by transplantation of demineralised bone mass. In some studies, MSCs were even applied intravenously, or into the distant part of the marrow cavity (Shirley et al. 2005).

In one study, mesenchymal stem cells were implanted on the hydroxyapatite matrix to the area of the alveolar crest of the jaw bone and to the segmental defects of femur in order to support new bone tissue growth. The results of the study demonstrated a significant growth of newly-formed bone tissue without any side effects (Pluhar 2004). At the same time, the effect of major histocompatibility complex (MHC) of suitability of allogeneic stem cells on the healing of long bone defects in dogs was monitored on pre-clinical models. Formation of systemic antibodies against implanted stem cells was not observed in the receptors.

The ground of our upcoming study is to verify the ability of MSCs to survive and the ability of their differentiation and consequent incorporation into the target tissue of the receptor in transplantation, in this case into the bone defect, partly in the mechanically resistant scaffold we are developing on the basis of hydroxyapatite, partly in direct combination with beta-tricalcium phosphate (ChronOs).

\section{Ligamentous and tendineous lesion healing}

Most studies on the treatment of tendineous or ligamentous defects present model cases of iatrogenically created defects of a gap nature (Thornton et al. 2003; Dressler et al. 2005), or resection of a certain part of the ligamentous complex (removal or excision of one part of the ligament (Beynnon et al. 1995); complete ligament excision and its subsequent suture (Hildebrand and Frank 1998)).

In studies we most frequently encounter stem cell transplantations to these target anatomical structures: ligamentum patellae (Beynnon et al. 1995; Awad et al. 2003), ligamentum collaterale mediale genu (Hildebrand and Frank 1998; Thornton et al. 2003) and ligamentum cruciatum anterior genu (Bray et al. 2003).

Rabbit is the generally used model of experimental animal in the mentioned studies (most often the New Zealand white rabbit) (Beynnon et al. 1995; Bray et al. 2003; Hildebrand and Frank 1998; Thornton et al. 2003). Other models include pigs (Moholkar et al. 2002), goats (Proctor et al. 1997) and horses (O’Sullivan 2005).

Stem cells have been most often transplanted with good results in a natural scaffold (mixing with bone marrow, mixing with collagen gel and implantation) (Harris et al. 2004; Dressler et al. 2005; O'Sullivan 2005; Awad et al. 2003), exceptionally in a synthetic scaffold (Adams et al. 2005). Mesenchymal stem cells in combination with bioabsorbable suture material used to treat an Achilles tendon rupture demonstrably improved the biochemical and structural properties of the healed area (Pluhar 2004). Within our national research project, we will perform MSC transplantation in combination with a newly developed scaffold on an experimental model of the anterior cruciate ligament rupture in the miniature pig.

Damages of the musculoskeletal system structures are commonly accompanied with serious functional problems and may be connected with lasting consequences in the form of invalidity. The hopes of modern science are therefore fixated on the search for optimal methods of treatment of the musculoskeletal system diseases by means of tissue engineering using stem cell transplantations. These methods comprise principles of biology and material engineering, serving the development of implants seeded with stem cells that would be capable of recovering, maintaining, or improving the functions of the damaged 
tissue. This synoptic study briefly summarizes the main trends of possible uses of MSCs in combination with biomaterials in the treatment of diseases affecting tissues derived from the mesoderm, i.e. articular cartilage, meniscus, physis, bone, ligaments and tendons.

\section{Biomateriály a kmenové buňky v léčbě defektů kloubních chrupavek, menisků, fyzárních plotének, kostí, vazů a šlach}

V této souhrnné práci je podán stručný přehled dosavadních výsledků a hlavních směrů experimentálních studií, zabývajících se možnostmi využití biomateriálů a mezenchymových kmenových buněk v léčbě chorob, které postihují tkáně derivované z mesodermu, tj. kloubní chrupavku, menisky, fýzu, kost, vazy a šlachy. Cílem experimentálních prací s touto tématikou je hledání optimálních forem léčby onemocnění jednotlivých součástí pohybového aparátu metodami tkáňového inženýrství s využitím transplantací kmenových buněk.

\section{Acknowledgement}

The study was supported by the Ministry of Education, Youth and Sports of the Czech Republic (Research Project NPV II 2B06130) and with the support of the Grant Agency AGEL-MH.

\section{References}

AHN JI, CANALE TS, BUTLER SD, HASTY KA 2004: Stem cell repair of physeal cartilage. J Orthop Res 22: $1215-221$

ADAMS SB, RANDOLPH MA, GILL TJ 2005: Tissue engineering for meniscus repair. J Knee Surg 18: 25-30

ANITUA E, ANDIA I, ARDANZA B 2004: Autologous platelets as a source of proteins for healing and tissue regeneration. Thromb Haemost 91: 4-15

ANITUA E, ANDIA I, SANCHEZ M 2005: Autologous preparations rich in growth factors promote proliferation and induce VEGF and HGF production by human tendon cells in culture. J Orthop Res 23:281-286

ARINZEH TL, PETER SJ, ARCHAMBAULT MP, BOS CH, GORDON S, KRAUS K, SMITH A, KADIYALA S 2003: Allogeneic mesenchymal stem cells regenerate bone in a critical-sized canine segmental defect. J Bone Joint Surg Am 85: 1927-35

AWAD HA, BOIVIN GP, DRESSLER MR, SMITH FNL, YOUNG RG, BUTLER DL 2003: Repair of patellar tendon injuries using a cell-collagen composite. J Orthop Res 21: 420

BATTEN P, SARATHCHANDRA P, ANTONIW JW, TAY SS 2006: Human mesenchymal stem cells induce $\mathrm{T}$ cell anergy and downregulate $\mathrm{T}$ cell allo-responses via the $\mathrm{TH} 2$ pathway: relevance to tissue engineering human heart valves. Tissue Eng 12: 2263

BEYNNON BD, DIRK P, DREZ DJ JR, STANKEWICH CJ, JOHNSON RJ 1995: Biomechanical assessment of the healing response of the rabbit patellar tendon after removal of its central third. Am J Sports Med 23: $452-457$

BRAY RC, LEONARD CA, SALO PT 2003: Correlation of healing capacity with vascular response in the anterior cruciate and medial collateral ligaments of the rabbit. J Orthop Res 21:1118-1123

CAMPBELL CJ, GRISOLIA A, ZANCONATO G 1959: The effects produced in the cartilaginous epiphyseal plate of immature dogs by experimental surgical traumata. J Bone Joint Surg Am 41: 1221-1242

CARTER K 2003: Growth factors: the wound healing therapy of the future. Br J Community Nurs 8: S15-23

CHEN G, USHIDA T, TATEISHI T 2002: Scaffold design for tissue engineering. Macromol Biosci 2: 67-77

CHEN G, USHIDA T, TATEISHI T 2000: A biodegradable hybrid sponge nested with collagen microsponges. J Biomed Mater Res 51: 273-279

CHEN F, HUI JHP, CHAN WK, LEE EH 2003: Cultured mesenchymal stem cell transfers in the treatment of partial growth arrest. J Pediatr Orthop 23: 425-429

DRESSLER MR, BUTLER DL, BOIVIN GP 2005: Effects of age on the repair ability of mesenchymal stem cells in rabbit tendon. J Orthop Res 23: 287-293

FANG Z, STARLY B, SUN W 2005: Computer-aided characterization for effective mechanical properties of porous tissue scaffolds. Comput Aided Des 37: 65-72

FARNWORTH L 2000: Osteochondral defects of the knee. Orthopedics 23: 146-159

FERRARI M, CORRADI A, LAZZARETTI M, DE'CILLÀ M, LOSI CG, VILLA R, LANFRANCHI A 2007 : Adult stem cells: Perspectives for therapeutic applications. Vet Res Commun 31:1-8

FORD LT, KEY JA 1956: A study of experimental trauma to the distal femoral epiphysis in rabbits. J Bone Joint Surg Am 38: 84-92

FORTIER LA, MOHAMMED HO, LUST G, NIXON AJ 2002: Insulin-like growth factor-I enhances cell-based repair articular cartilage. J Bone Joint Surg Br 84: 276-288

FORTIER LA, NIXON AJ, WILLIAMS J 1998: Isolation and chondrocytic differentiation of equine bone marrow-derived mesenchymal stem cells. Am J Vet Res 59: 1182-1187 
GÁL P, NEČAS A, ADLER J, TEYSCHL O, FABIÁN P, BIBROVÁ Š 2002: Transplantation of the autogenous chondrocyte graft to physeal defects: an experimental study in pigs. Acta Vet Brno 71: 327-332

GÁL P, NEČAS A, PLÁNKA L, KECOVA H, KŘEN L, KRUPA P, HLUČILOVÁ J, USVALD D 2007: Chondrocytic potential of allogenic mesenchymal stem cells transplanted without immunosuppression to regenerate physeal defect in rabbits. Acta Vet Brno 76: 265-275

GOHO A 2004: Bonelike polymer supports stem cells. Sci News 166: 401

GRANDE DA, MASON J, LIGHT E, DINES D 2003: Stem cells as platforms for delivery of genes to enhance cartilage repair. J Bone Joint Surg Am 85: 111-116

HARRIS MT, BUTLER DL, BOIVIN GP, FLORER JB, SCHANTZ EJ, WENSTRUP RJ 2004: Mesenchymal stem cells used for rabbit tendon repair can form ectopic bone and express alkaline phosphatase activity in constructs. J Orthop Res 22: 998-1003

HILDEBRAND KA, FRANK CB 1998: Scar formation and ligament healing. Can J Surg 41: 425-429

HOEMANN CD, HURTIG M, ROSSOMACHA E, SUN J, CHEVRIER A, SHIVE MS, BUSCHMANN MD 2005: Chitosan-glycerol phosphate/blood implants improve hyaline cartilage repair in ovine microfracture defects. J Bone Joint Surg Am 87: 2671-86

HUI JHP, LI L, TEO YH, OUYANG HW, LEE EH 2005: Comparative study of the ability of mesenchymal stem cells derived from bone marrow, periosteum, and adipose tissue in treatment of partial growth arrest in rabbit. Tissue Eng 11: 904-912

JANARV PM, WIKSTRÖM B, HIRSCH G 1998: The influence of transphyseal drilling and tendon grafting on bone growth: an experimental study in the rabbit. J Pediatr Orthop 18: 149-154

JANČÁR J, SLOVÍKOVÁ A, AMLER E, KRUPA P, KECOVÁ H, PLÁNKA L, GÁL P, NEČAS A 2007a: Mechanical response of porous scaffolds for cartilage engineering. Physiol Res 56 (Suppl): S17-S25

JANČÁŘ J, SLOVÍKOVÁ A, NEČAS A, KRUPA P, PLÁNKA L 2007b: Tensile and compressive response of bionanocomposites based on collagen reinforced with chitosan nanofibers. In: Abstract Book of the Second International Conference on Mechanics of Biomaterials \& Tissues, December 9-13. Lihue, Kauai, Hawai, USA, p. 107

LANGENSKIÖLD A 1981: Surgical treatment of partial closure of the growth plate. J Pediatr Orthop 1: 3-11

LEE EH, CHEN F, CHAN J, BOSE K 1998: Treatment of growth arrest by transfer of cultured chondrocytes into physeal defects. J Pediatr Orthop 18: 155-160

LEE EH, HUI HP 2006: The potential of stem cells in orthopaedic surgery. J Bone Joint Surg Br 88: 841-851

LENNOX DW, GOLDNER RD, SUSSMAN MD 1983: Cartilage as an interposition material to prevent transphyseal bone bridge formation: an experimental model. J Pediatr Orthop 3: 207-210

MACKSOUD WS, BRIGHT R 1989: Bar resection and silastic interposition in distal radial physeal arrest. Orthop Trans 13: 1-2

MANN DC, RAJMAIRA S 1990: Distribution of physeal and nonphyseal fractures in 2650 long-bone fractures in children aged 0 - 16 years. J Pediatr Orthop 10: 713-716

MARX RE 2004: Platelet-rich plasma: evidence to support its use. J Oral Maxillofac Surg 62: 489-496

MELAMED E, ROBINSON D, HALPERIN N, NEVO Z 2004: Restoration of arthritic cartilage defects using autologous chondrocytes transplantation is superior to cartilage-paste graft in rabbits. J Knee Surg 17: 6-12

MOHOLKAR K, TYLOR D, O'REAGAN M, FENELON G 2002: A biomechanical analysis of four different methods of harvesting bone-patellar tendon-bone graft in porcine knees. J Bone Joint Surg Am 84: 1782-1787

MORONI L, DE WINJ LR, VAN BLITTERSWIJK CA 2006: 3D fiber-deposited scaffolds for tissue engineering: Influence of pores geometry and architecture on dynamic mechanical properties. Biomaterials 27: 974-985

NEWBERRY WN, ZUKOSKY DK, HAUT CR 1997: Subfracture insult to a knee joint causes alterations in the bone and in the functional stiffness of overlying cartilage. J Orthop Res 15: 450-456

NEČAS A, GÁL P, ADLER J, KECOVÁ H, FABIÁN P, BIBROVÁ Š 2006: Transplantation of the autogenous chondrocyte graft to physeal defects: An experimental study. Proceedings of the $2^{\text {nd }}$ Annual World Orthopedic Congress, 25. 2. - 4. 3. 2006. Keystone, Colorado, USA, p. 236

O'DRISCOLL SW 1998: Current concepts review: The healing and regeneration of articular cartilage. J Bone Joint Surg Am 80: 1795-1812

O’SULLIVAN C 2005: Stem cells may save cup campaigns. Australas Sci 26: 26-28

ÖSTERMAN K 1972: Operative elimination of partial premature epiphyseal closure. An experimental study. Acta Orthop Scand Suppl 147: 3-79

PAŠA L, NEČAS A, PIPERISOVÁ I, KECOVÁ H, VIŠŇA P, TICHÝ F 2005: Experimental meniscal allografts in the rabbit. Acta Vet Brno 74: 87-95

PLÁNKA L, NEČAS A, GÁL P, KECOVÁ H, FILOVÁ E, KŘEN L, KRUPA P 2007: Prevention of bone bridge formation using transplantation of the autogenous mesenchymal stem cells to physeal defects: An experimental study in rabbits. Acta Vet Brno 76: 253-263

PLUHAR GE 2004: Orthopedic application of mesenchymal stem cells. Proceedings of the ACVS Veterinary Symposium, October 6. - 9. 2004. Denver, Colorado, USA, pp. 326-328

PLUMAS J, CHAPEROT L, RICHARD MJ, MOLENS JP 2005: Mesenchymal stem cells induce apoptosis of activated T cells. Leukemia 19: 1597-1604 
PROCTOR CS, JACKSON DW, SIMON TM 1997: Characterization of the repair tissue after removal of the central one-third of the patellar ligament. J Bone Joint Surg Am 79: 997-1006

RISBUD MV, SITTINGER M 2002: Tissue engineering: advances in in vitro cartilage generation. Trends Biotechnol 20: 351-355

SMITH RKW 2006: Mesenchymal stem cells - theory and application 2006: Proceedings of the $15^{\text {th }}$ Annual Scientific Meeting, June 29-July 1, 2006. Sevilla, Spain, pp. 207-210

SHIRLEY D, MARSH D, JORDAN G, MCQUAID S, LI G 2005: Systemic recruitment of osteoblastic cells in fracture healing. J Orthop Res 23: 1013-1021

SZPALSKI M, GUNZBURG R 2002: Applications of calcium phosphate-based cancellous bone void fillers in trauma surgery. Orthopedics 25: 601-609

THORNTON GM, SHRIVE NG, FRANK CB 2003: Healing ligaments have decreased cyclic modulus compared to normal ligaments and immobilization further compromises healing ligament response to cyclic loading. J Orthop Res 21: 716-722

TERROVITIS JV, BULTE JWM, SARVANANTHAN S, CROWE LA, SARATHCHANDRA A, BATTEN P, SACHLOS E, CHESTER AH, CZERNUSZKA JT, FIRMIN DN, TAYLOR PM, YACOUB MH 2006: Magnetic resonance imaging of ferumoxide-labeled mesenchymal stem cells seeded on collagen scaffoldsrelevance to tissue engineering. Tissue Eng 12: 2765-2775

WILKE M, NIXON AJ, ADAMS TA 2001: Enhanced early chondrogenesis in equine cartilage defects using implanted autologous mesenchymal stem cells. Vet Surg 30: 508-509

YANAI T, ISHII T, CHANG F, OCHIAI N 2005: Repair of large full-thickness articular cartilage defects in the rabbit: The effects of joint distraction and autologous bone-marrow-derived mesenchymal cell transplantation. J Bone Joint Surg Br 87: 721-729 
Plate VI

Nečas A. et al.: Biomaterials ... pp. 277-284

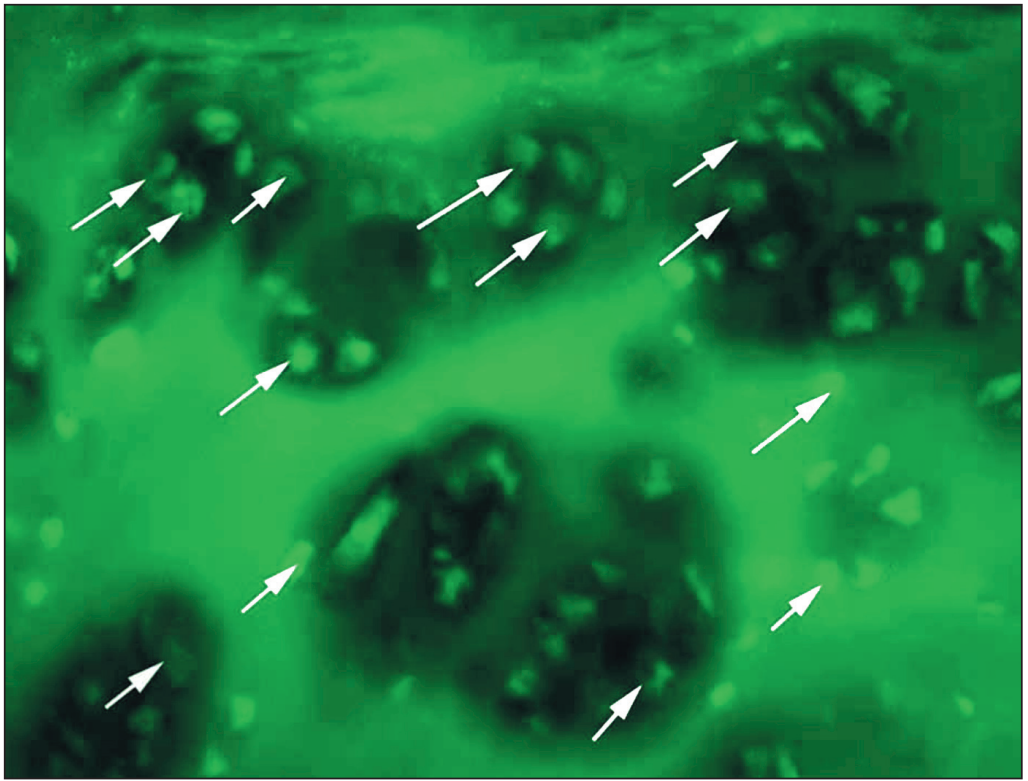

Fig. 1. Immunofluorescence. Proof of the DiI stain on the chondrocyte membranes (arrows) differentiated from the implanted allogeneic MSCs $(\times 400)$

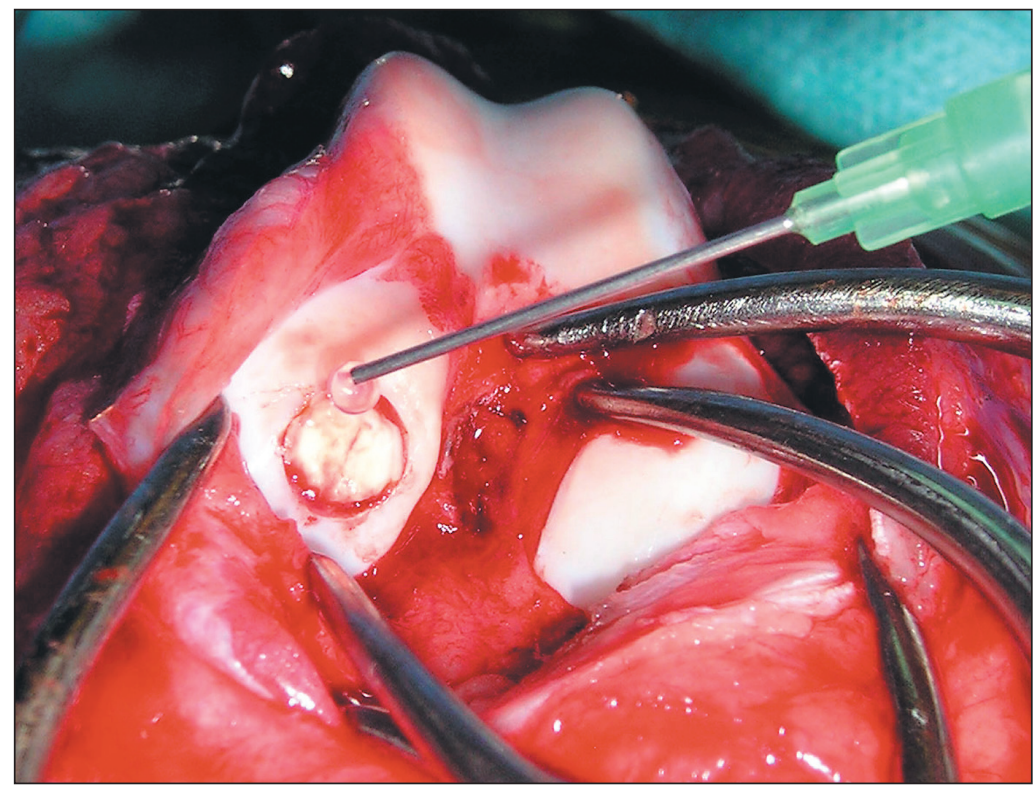

Fig. 2. Transplantation of MSCs. Defect of the articular cartilage surface on the lateral condyle of femur of a miniature pig is filled with an implanted scaffold with MSCs 